Published on Reviews in History (https://reviews.history.ac.uk)

\title{
Sir Edward Coke and the Reformation of the Laws: Religion, Politics and Jurisprudence, 1578-1616
}

\author{
Review Number: 1827
}

Publish date: Wednesday, 9 September, 2015

Author: David Chan Smith

ISBN: 9781107069299

Date of Publication: 2014

Price: $£ 63.00$

Pages: 308pp.

Publisher: Cambridge University Press

Publisher url: http://www.cambridge.org/gb/academic/subjects/law/legal-history/sir-edward-coke-and-reformationreligion-politics-and-jurisprudence-15781616?format $=\mathrm{HB}$

Place of Publication: Cambridge

Reviewer: Daniel Gosling

To say that Sir Edward Coke is a much-studied man is somewhat of an understatement. However, in Sir Edward Coke and the Reformation of the Laws David Chan Smith has managed to craft a history of the great Elizabethan and Jacobean jurist that sets itself apart from other histories, in viewing Coke's life through the prism of his legal reforms, rather than offering another general biography of the English common lawyer.

Smith acknowledges the wealth of existing literature on Edward Coke early on in his discussion (p. 1), specifically identifying a total of eleven biographies ranging from Cuthbert Johnson's The Life of Sir Edward Coke, published in 1837, to more recent contributions such as Allen Boyer's Sir Edward Coke and the Elizabethan Age, published in 2003.(1) Additionally, Smith identifies a number of separate works that delve into different aspects of Coke's character and use of the law, from Charles Gray's analysis of his use of the Writ of Prohibition, to George Garnett's analysis of Coke's abilities as an historian.(2) Instead of repeating the content of these works, Smith's text instead looks to reframe the origins of Coke's legal thought within the context of law reform, and in so doing provide a new interpretation of Coke's early career, the development of his legal though, and ultimately his path from royalism to opposition. It is this final point that is most strongly argued throughout the book.

Smith disagrees with the argument that there were two clearly defined schools of thought regarding 17thcentury law reform: that on the one hand stood the monarch, typically seeking to defend his royal prerogatives/abuses against the legal curbs on them, with, on the other hand, a body of common lawyers, arguing for equal rights and freedoms, and thus sometimes acting against the wishes of the monarch. Coke's own career trajectory from royalism to opposition demonstrates that this argument is oversimplified. The main argument of the text is that tensions surrounding 17th-century law reform were instead created through disagreements over the way that such reform should come about. Thus there was nothing within Coke's proposals for law reform that placed him in the camp of royal oppositionists (at least not up to 1616, when the narrative of the book ends). Instead tensions between the king and Coke came about because James I did not share in Coke's vision of the operation of legal power (p. 10). It is this reinterpretation of Coke's vision 
that provides the new lens through which Coke's career up to 1616 - when he was removed from the Bench by the king - is convincingly assessed in the book.

The first chapter of the book deals with Coke's early career, and attempts to establish what influenced Coke's own ideas regarding the English common law by describing the state of the common law, and the opinions of contemporaries on the topic of law reform, at the turn of the 17th century. Continuing to eschew mere biography, Smith covers the lawyer's early life, from his birth on 1 February 1552 to his being called to the Bar in 1578, in just one paragraph. This is not, however, to the detriment of describing Coke's professional development, and this paragraph includes his early days at Norwich Grammar, through his enrolment at Trinity College, Cambridge as a pensioner in 1567, which he left without taking a degree in 1570, to his entry into Clifford's Inn on 21 January 1571, and then on 24 April 1572 to the more prominent Inner Temple (pp. 20-1).

Coke gained a reputation for brilliance once at the Inner Temple, and appeared in numerous cases (pp. 21-2). He gave a reading on the Statute of Fines at Lyon's Inn in 1579, and was appointed to offices of responsibility shortly after, including the recorderships of Coventry (1585) and Norwich (1586). In 1586 he was appointed as a Justice of the Peace in Norfolk, in 1593 for Suffolk and Middlesex, and was an MP in 1589 for Aldeburgh, Suffolk and in 1593 for Norfolk (p. 22). These appointments are similarly summarised in a single paragraph. That Coke's early career is so swiftly described is no doubt in an effort to avoid the relatively recent Sir Edward Coke and the Elizabethan Age by Allen Boyer, which analysed Coke's career up to 1603 in great detail.(3) As is made clear in the introduction to Smith's text, such biographical information is incidental to the analysis of Coke's legal reforms, and instead the book focuses far more on the cases that shaped Coke's legal development, rather than on prestigious appointments. Thus, more space is given for an analysis of Shelley's Case (1581), where Coke experienced the uncertainty of the law firsthand as a barrister (p. 22).

Chapter one also examines the general attitude to law reform amongst Coke's contemporaries. Leading professionals shared unease about how the legal system operated (p. 23). There was an awareness on thepart of Coke and others that the regeneration of the common law begun under the leadership of Sir John Fyneux in the early Tudor period had brought with it unforeseen problems that had corrupted the English common law (p. 26). The text leaves the reader in little doubt that at the turn of the 17th century the common law was in vital need of reform. This chapter also examines possible methods of reform, such as reform by statute, which were pursued by Coke and others in the early 17th-century parliaments, and the possible obstacles to reform, the most pervasive being the sheer complexity of the English common law system and its various overlapping and contradictory jurisdictions. Finally, this chapter concludes with one way in which Coke attempted to simplify the law, in the composition of his Reports, the first part of which was published in 1600. However, the text emphasises that Coke was not trying to distance the common law from the king, and instead positioned his reforming activities as a response to James I's demands, coming back to the general concern of the book: to explain Coke's shift from royalist to opposition (p. 58).

Chapter two continues the ideas introduced in chapter one, explaining how Coke's own reforming proposals developed from his early professional experience in the late Elizabethan period. The foundation of Coke's interpretation of the English common law was that all legal authority was a delegation from the monarch, who received it from God. Thus Coke was not afraid, even early on in his career, to pursue those trusted with royal authority who had abused it. Coke developed the treason law whilst serving under the Elizabethan warstate, infusing it with his own ideas about royal power. In this chapter is seen both Coke's belief in the theory of crown justice, but also his determination to hold those misusing royal justice to account.

Chapter three looks in more detail at the corruption of the law in the early 17th century, and the complaints of those that were expected to use it. The text does this by examining the case-study of The Case of the Isle of Ely (1609), which saw Coke attempt to negotiate the proposed draining of the Fens, the low-land area of marsh and bog in the east of England. This was such a thorny issue because in order to drain the Fens taxes would have to be raised in the surrounding areas, and parts of the Fens would have to be enclosed to 
incentivise investors. Although this case-study demonstrated how contentious the common law could be amongst the wider population, and how Coke attempted to solve the problems, this chapter more than any of the others feels like an unnecessary digression from the wider argument, with too much time spent looking at the law in the Fens rather than the more pressing topic of common law reform that the rest of the book had set about to describe.

Chapter four brings Coke's personal views of law reform back into focus by analysing the lawyer's historical writings, and they were shaped to support his legal opinions. In them Coke defended the common law and demonstrated how the Crown and the law had always worked in tandem with each other: kings and queens had always been instrumental in recording, changing and augmenting the law; just as the common law protected the monarch, most obviously from popish plots. Coke argued this latter point by using the works of Protestant apologists such as William Tyndale and John Foxe. It is in this chapter that Smith's revised history of Coke's jurisprudence begins to take shape, and explains how Coke could be both a believer in the power of the monarchy but also a critic of the king later on. This argument continues in chapter five, which describes Coke's awareness of the difficulties apparent in practical law reform, and demonstrates how Coke's own opinions were shaped by these problems. In this chapter Smith tackles the complex distinctions between common and civil law, written and oral memory, and the idea of law as reason. These distinctions preoccupied Coke when he was developing his law reforms, and allowed him to explain the failings of the reforms proposed by his contemporaries.

Chapters six and seven are case studies that examine Coke's relationship with the courts of High Commission (for Causes Ecclesiastical) and Chancery. Both of these courts had expanded their jurisdictions during the late 15th and early 16th centuries to a point where the lawyers of the courts of Common Pleas and King's Bench had cause for concern. Among these was Sir Edward Coke, whose argument for reform rested on a law which was consistent; encroaching jurisdictions between courts only served to muddy the waters of reform. One of the chief claims the men of High Commission and Chancery made regarding their right to expand their jurisdictions was that each court had been set up by the Crown; as with the court of King's Bench, to challenge the validity of either of these courts was to challenge the king. At least that was how James I interpreted it when Coke made his arguments against these so-called abuses in these courts. Both these chapters work well in setting up the final chapter of the book, where Coke's relationship with the monarch and his understanding of how the royal prerogative and the common law worked together (in theory) are described.

The definition of the common law, in Coke's opinion, was the law of the king's justice. Thus the justices of the common law courts were acting on behalf of the king. The main issue that Coke had to deal with was that though royal justice was infallible, the monarch who exercised it was not, and the justices of the law courts even less so. Coke proposed that to ensure that royal justice was not tarnished as it percolated down into the common law, the monarch should refrain from judging in his own person in order to immunise himself from the moral consequences of an error that had no appeal. Coke's main opposition to this approach was unfortunately King James I, whose upbringing in Scotland under Scots law made him far more sceptical of the English common law. Thus the king's approach to common law reform naturally differed drastically from Coke's. 
One minor quibble in this otherwise impressive and comprehensive study is that at times the author does not explain characters mentioned in the narrative sufficiently. For example, the book opens with a comparison of two quotes: one from Coke, and one from Lord Mansfield (p. 1). Although legal historians of the 17th century and later will be aware that William Murray, Lord Mansfield, was Chief Justice of the King's Bench between 1756 and 1788, this may not be the case for many others looking to utilise this book. Similarly, Smith in Chapter one describes Coke's preoccupation with the consequences of the 'regeneration' of the common law begun under the leadership of Sir John Fyneux (p. 26). However, at no point is it explained that Fyneux was Chief Justice of the King's Bench from 1495 until his death in 1525. Again, to many students of the English common law the person of Sir John Fyneux will be well-known; however his occupation and dates of service in the common law would serve to make the book more accessible.

Despite this minor criticism, Sir Edward Coke and the Reformation of the Laws has much to offer historians of the common law and the period in which Coke lived. Smith has written an impressive legal history drawing on a huge range of legal cases and reports, and managed to craft them into a readable account of Coke's law reforms, whilst placing these reforms in the context of his age. No easy feat, yet one handled admirably by Smith.

\section{Notes}

1. Cuthbert Johnson, The Life of Sir Edward Coke (London, 1837); Allen Boyer, Sir Edward Coke and the Elizabethan Age (Stanford, CA, 2003).Back to (1)

2. Charles Gray, The Writ of Prohibition: Jurisdiction in Early Modern English Law (Chicago, IL, 1994); George Garnett, "'The ould fields": Law and History in the Prefaces to Sir Edward Coke's Reports', The Journal of Legal History, 34, 3 (2013), 245-84.Back to (2)

3. Allen Boyer, Sir Edward Coke and the Elizabethan Age (Stanford, CA, 2003).Back to (3)

Source URL:https://reviews.history.ac.uk/review/1827

\section{Links}

[1] https://reviews.history.ac.uk/item/137245 